\title{
Bed bug bites mimicking bullous pemphigoid: a report of two cases
}

\author{
Ugryzienia przez pluskwy domowe imitujące pemfigoid pęcherzowy - opis dwóch \\ przypadków
}

Aleksandra Wieczorek', Jacek Szepietowski², Katarzyna Łoza', Andrzej Bizoń', Julia Lanckorońska', Karolina Rutkowska', Katarzyna Głogowska'

'Department of Dermatology for Adults, Center of Dermatology, Miedzyleski Specialist Hospital, Warsaw, Poland 2Department of Dermatology, Venereology and Allergology, Wroclaw Medical University, Wroclaw, Poland

Przegl Dermatol 2016, 103, 281-284 DOI: 10.5 | |4/dr.2016.61775

KEY WORDS:

bed bug, Cimex lectularius, autoimmune bullous diseases.

SŁOWA KLUCZOWE:

pluskwa domowa, Cimex lectularius, autoimmunologiczne choroby pęcherzowe.
ADDRESS FOR CORRESPONDENCE:

Aleksandra Wieczorek MD

Department of Dermatology

for Adults

Center of Dermatology

Miedzyleski Specialist Hospital

2 Bursztynowa St

04-749 Warsaw

phone: +48 509819206

e-mail: awieczorek85@interia.pl

\section{ABSTRACT}

Introduction. Bed bugs belong to the family Cimicidae, which includes two cosmopolitan species: Cimex lectularius and Cimex hemipterus. Bed bugs feed on the blood of humans and animals. As a result of bites, skin changes can manifest as itchy spots, erythematous-edematous lesions, hives and bullae.

Aim. To describe two cases: a father and daughter living in the same household, both having skin lesions after bed bug bites that could imitate autoimmune bullous diseases.

Case reports. The first case concerns a 57-year-old man on whose trunk and extremities were erythematous-edematous lesions and bullae. The second case concerns the 34-year-old daughter of the first patient, on whose trunk and extremities were linear erythematous-edematous lesions. Both in the first and second case direct and indirect immunofluorescence was negative.

Conclusions. Bed bug bites can mimic other skin diseases, including autoimmune bullous diseases.

\section{STRESZCZENIE}

Wprowadzenie. Pluskwa domowa należy do rodziny Cimicidae, w której wyróżnia się dwa kosmopolityczne gatunki Cimex lectularius oraz Cimex hemipterus. Pluskwy żywią się krwią ludzką oraz zwierzęcą. Zmiany skórne powstałe w wyniku pogryzień mogą mieć postać swędzących plam, ognisk rumieniowo-obrzękowych, bąbli pokrzywkowych oraz pęcherzy.

Cel pracy. Opis dwóch przypadków - ojca i córki, mieszkających razem, których zmiany skórne po pogryzieniu przez pluskwy domowe imitowały autoimmunologiczne choroby pęcherzowe.

Opis przypadków. Pierwszy przypadek dotyczy 57-letniego mężczyzny, u którego na skórze tułowia i kończyn pojawiły się zmiany rumieniowo-obrzękowe oraz pęcherze, natomiast drugi przypadek 34-letniej córki pacjenta, u której na skórze tułowia i kończyn były obecne linijne zmiany rumieniowo-obrzękowe i pęcherzyki. Zarówno w pierwszym, jak i drugim przypadku wyniki badania immunopatologicznego bezpośredniego i pośredniego były ujemne.

Wnioski. Pogryzienia przez pluskwę domową mogą imitować inne choroby skóry, w tym autoimmunologiczne choroby pęcherzowe. 


\section{INTRODUCTION}

Bed bugs belong to the insect family of Cimicidae [1]. They feed on the blood of humans and animals [1]. The family includes two cosmopolitan species: Cimex lectularius living in moderate climates, and $\mathrm{Ci}$ mex hemipterus living mainly in the tropical zone [2]. A female bed bug can reach a length of $7 \mathrm{~mm} \mathrm{[2].}$ The male usually has smaller dimensions [3]. It is possible that the amount of blood absorbed significantly exceeds the weight of the parasite, increasing the size and weight of the insect $[1,3]$. The bed bug is a flat, brownish-red wingless arthropod [2]. In the literature it is sometimes compared to the seeds of apples [4]. The color of the body is dependent on the stage of satiety. Hungry bed bugs are transparent, while a satiated one can change to a red-brown color [3]. In the region of the third leg pair, bed bugs have glands that secrete an unpleasant odor comparable to the smell of coriander $[3,5]$. A mature bed bug feeds usually three to five times daily, dedicating $10 \mathrm{~min}$ to each meal [1]. The female bed bug lays about two to three eggs per day, which develop into larvae and

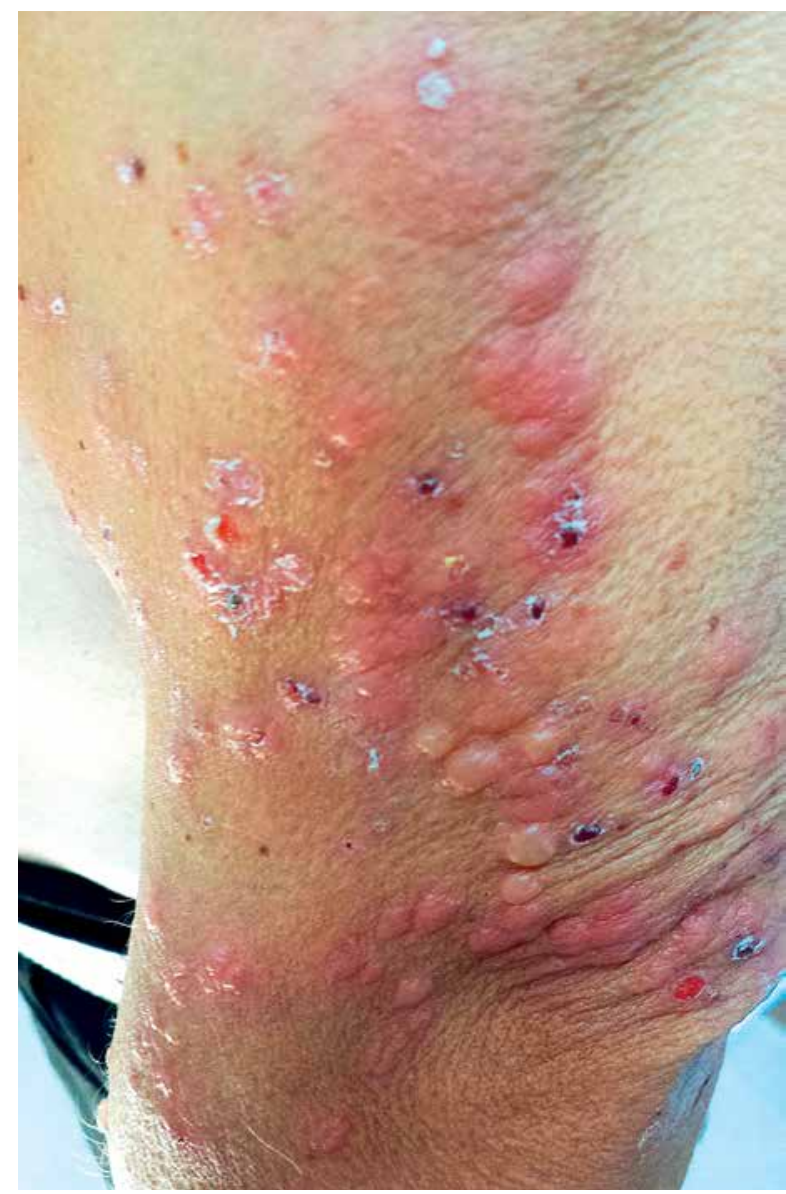

Figure I. Yellow bullae and erythematous-edematous skin lesions on the left arm

Rycina I. Zółte pęcherze oraz zmiany rumieniowo-obrzękowe na lewym ramieniu nymphs in 1-2 months [3]. In order to reach maturity, nymphs must molt four times, which is possible only after a meal containing blood [4]. Bed bugs can survive without food for a very long time [3]. It is estimated that they can survive without food even for a year [1]. In recent times there have been reports that bed bugs can be a vector for a variety of pathogens such as viruses, bacteria and protozoa [6]. Therefore, detection of these insects is very important from the epidemiological point of view [6-8], especially in cases of emergency pathogens such as Staphylococcus aureus (MRSA) and vancomycin-resistant Enterococcus faecium (VRE) [8]. Bed bugs are a likely vector of hepatitis B virus. In the case of viruses such as HIV or hepatitis $C$ virus, the bed bug seems to have no significance [6]. Its role in the transmission of the protozoan Trypanosoma cruzi is not entirely clear [7].

\section{OBJECTIVE}

The aim of this paper is to present two cases: a father and his daughter living in the same household, both with lesions after bed bug bites imitating autoimmune bullous diseases.

\section{CASE REPORTS}

\section{Case I}

A 57-year-old patient came to the Department of Dermatology for Adults in the Miedzyleski Specialist Hospital in Warsaw in early October 2015. The patient complained of disseminated bullous skin changes. He presented with edematous and erythematous lesions accompanied by severe pruritus. Symptoms had appeared about 3 weeks prior to admission. He was treated in an outpatient clinic with acyclovir and topical ointment containing zinc with no improvement. The patient gave a history of hypothyroidism, prostatic hypertrophy and depression. A few months earlier he moved to a new apartment where he lived with his daughter. On admission the patient presented with pruritic erythematous and edematous skin changes, erosions partially covered with crusts and tense bullae located on both lesional and non-lesional skin of the trunk and upper and lower extremities. Some of the skin changes had a linear arrangement, while others were grouped (Fig. 1). Face, scalp and mucous membranes were free of lesions. Laboratory examinations showed elevated levels of erythrocyte sedimentation rate (ESR), D-dimer, uric acid, total cholesterol and IgE in the serum. A slightly elevated number of eosinophils was present in the blood smear. Bullous pemphigoid was suspected. Direct and indirect immunofluorescence tests were negative. We also performed histopatho- 


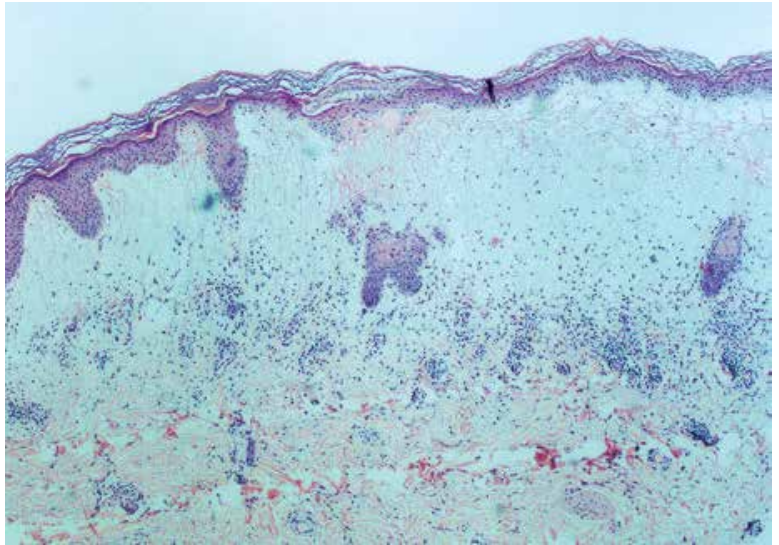

Figure 2. Histopathological examination. Bulla filled with fluid and deposits of fibrin

Rycina 2. Badanie histopatologiczne. Pęcherz mppełniony płynem i złogami włóknika

logical examination of the bullous lesion, which revealed epidermis with foci of parakeratosis. Beneath the epidermis there was a bulla filled with fluid and deposits of fibrin. In the subcutaneous tissue inflammatory lymphocytic infiltration around small vessels was present (Fig. 2).

Due to the suspicion of autoimmune bullous disease, treatment with corticosteroids (dexamethasone $8 \mathrm{mg}$ twice daily), tetracycline, antihistamines and topical corticosteroids and emollients was introduced. The patient responded well to the therapy and his condition improved. He was discharged home on topical glucocorticosteroids therapy and emollients. After returning home the patient discovered insects inside the sofa he slept on (Fig. 3). He decided to change the flat. He continued the prescribed medication. At present the patient is being followed up and has clear skin.

\section{Case 2}

A woman aged 34 in good general condition attended the Department of Dermatology for Adults in Miedzyleski Specialist Hospital in Warsaw in late October 2015. On admission the patient complained of itchy erythematous and edematous lesions and vesicles in the area of the neck, buttocks, thighs and arms (Fig. 4). These symptoms appeared about 4 weeks prior to admission. The patient lived with her father in a new flat. Laboratory tests showed a slightly elevated level of indirect bilirubin in the serum. Other values were within the normal limits. Direct and indirect immunofluorescence tests were negative. After detailed history taking, insect bite reaction was suspected. The patient was treated with a topical corticosteroid with good results. She did not come for a checkup in the outpatient clinic. Her father informed of complete resolution of symptoms in his daughter.

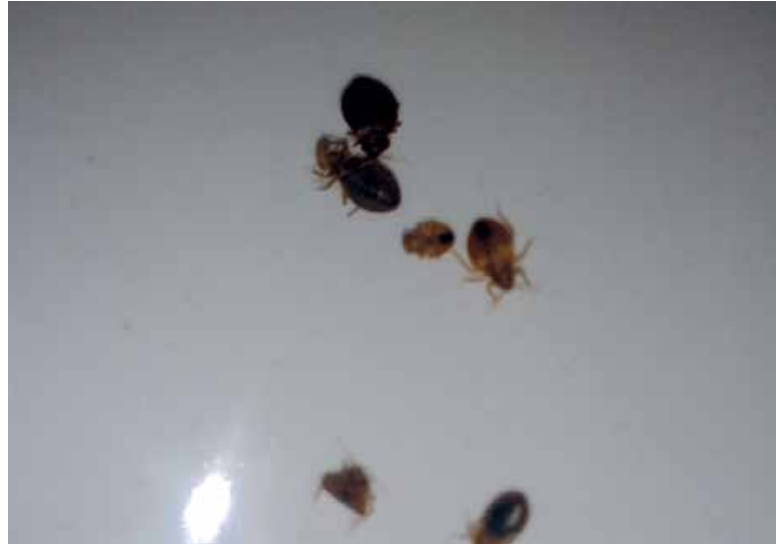

Figure 3. Picture of the bed bugs

Rycina 3. Osobniki pluskwy domowej

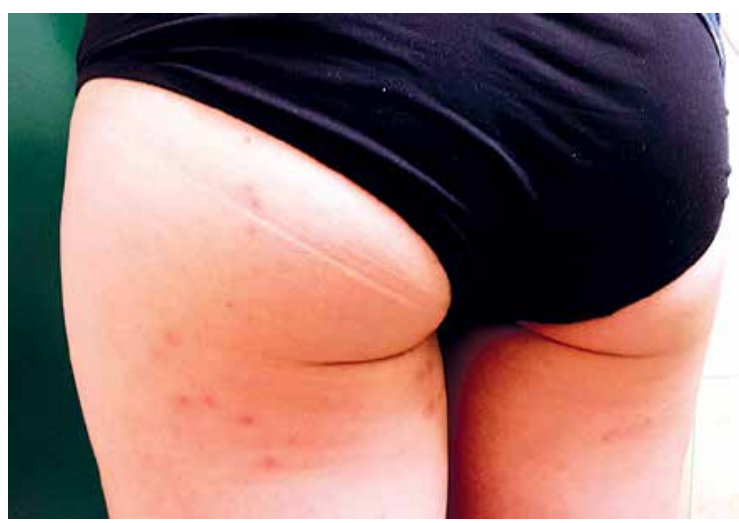

Figure 4. Erythematous-edematous lesions and vesicles on the buttocks and thighs

Rycina 4. Zmiany rumieniowo-obrzękowe oraz pęcherzyki w okolicy pośladków i ud

\section{DISCUSSION}

Detailed data on the epidemiology and prevalence of bed bugs in the world are limited [6]. The occurrence of insects is associated with a high population density and poor hygienic conditions [6]. Bed bugs usually are present in the surroundings of households with large population centers, i.e. in hotels, dormitories, hospitals, ships or shelters for the homeless [4, 6, 8-10]. In the latter case, the frequency of bites is about 30\% [10]. Bed bugs usually hide in beds, headboards and under mattresses [6]. They move along cables, finding their way through electric sockets [3]. The insects can also easily travel as "stowaways" with people, hidden in clothes, bags or luggage [9]. One way of transmission reported was by furniture [9]. They can travel long distances, settling in new feeding sites $[1,11]$.

Bed bug bites are painless due to anesthetic substances contained in the insect saliva as well as vasodilator and antithrombotic factors [1, 2]. Skin lesions resulting from insect bites can be erythematous, edematous, papular, in the form of spots and 
hemorrhagic lesions. Very often they are accompanied by itching. Swelling of the face and bullae are less frequent $[3,11-14]$. The bites typically have a linear arrangement which is described in the literature as "breakfast, lunch, dinner". The reactions are also called "bed bug dermatitis" [11]. Insects usually seek food at night, choosing naked parts of the victim's body [1, 13]. Bed bug biting usually disturbs sleep [13].

Due to the diverse morphology of lesions, bed bug bites should be differentiated from other diseases. The most commonly taken into account are bites by other arthropods such as mosquitoes or fleas [3]. The differential diagnosis should also consider acute urticaria, papular urticaria, prurigo simplex acuta, erythema multiforme and strophulus [3, 15].

In this paper we wanted to show that bed bug bites may provoke bulla and vesicles, which can mimic bullous diseases such as bullous pemphigoid or Duhring's disease. In the first patient, we observed tense bullae on both lesional and non-lesional skin. In the second case skin changes were manifested in the form of erythematous and edematous lesions, with associated vesicles. Both the father and his daughter complained of itching.

The diagnosis in both cases was established on the basis of a detailed history, clinical manifestations, presence of insects and improvement after treatment as well as a change of the place of living. A key factor in the first case was the appearance of skin changes in the patient's daughter in the same period of time, prompting the search for the parasitic etiology. Negative results of direct and indirect immunofluorescence tests excluded autoimmune bullous diseases.

\section{Conflict of interest}

The authors declare no conflict of interest.

Submitted: 24 II 2016

Accepted: 11 VII 2016

\section{References}

1. Fedor D.N.: Bed bugs (Cimex lectularius). Biology, control methods and their role as pests. MUSe 2014, 1, 153-157.

2. Delaunay P., Blanc V., Del Giudice P., Levy-Bencheton A., Chosidow O., Marty P., et al.: Bedbugs and infectious disease. Clin Infect Dis 2011, 52, 200-210.

3. Rufli T.: Choroby wywołane przez stawonogi. [in:] BraunFalco Dermatologia. W.H.C. Burgdorf, G. Plewig, H.H. Wolff, M. Landthaler (eds). Wydawnictwo Czelej, Lublin, 2010, 339.

4. Fallen R.S., Gooderham M.: Bedbugs: an update on recognition and management. Skin Ther Lett 2011, 16, 5-7.

5. Juckett G.: Arthropod bites. Am Fam Physician 2013, 88, 841-847.

6. Goddard J., de Shazo R.: Bed bugs (Cimex lectularius) and clinical consequences of their bites. JAMA 2009, 301, 13581366.

7. Salazar R., Castillo-Neyra R., Tustin A.W., Borrini-Mayorı K., Naquira C., Levy M.Z.: Bed bugs (Cimex lectularius) as vectors of Trypanosoma cruzi. Am J Trop Med Hyg 2015, 92, 331-335.

8. Lowe C.F., Romney M.G.: Bedbugs as vectors for drug-resistant bacteria. Emerg Infect Dis 2011, 17, 1132-1134.

9. Lee I.Y., Ree H.I., An S.J., Linton J.A., Yong T.S.: Reemergence of the bedbug Cimex lectularius in Seoul, Korea. Korean J Parasitol 2008, 46, 269-271.

10. Hwang S.W., Svoboda T.J., De Jong I.J., Kabasele K.J., Gogosis E.: Bed bug infestations in an urban environment. Emerg Infect Dis 2005, 11, 533-538.

11. Filho F.B., Quaresma M.V., Avelleira J.C.R., Azulay D.R., Azulay-Abulafia L., Queiros Bastos A., et al.: Bed bug dermatitis, description of two cases in Rio de Janeiro, Brazil. An Bras Dermatol 2015, 90, 240-243.

12. Cooper D.L.: Can bedbug bites cause bullous erythema? JAMA 1948, 138, 1206.

13. Scarupa M.D., Economides A.: Bed bug bites masquerading as urticaria. J Allergy Clin Immunol 2006, 117, 15081509.

14. Goddard J., Edwards K.T., de Shazo R.D.: Observations on development of cutaneous lesions from bites by the common bed bug, Cimex lectularius L. Midsouth Entomologist 2011, 4, 49-52.

15. Hamburger F., Dietrich A.: Lichen urticatus exogenes. Acta Paediatr 1937, 22, 420. 